\title{
Which component of sulphasalazine is active in rheumatoid arthritis?
}

\author{
T PULLAR, J A HUNTER, H A CAPELL
}

\begin{abstract}
Sulphasalazine is known to be effective as a second line agent in the treatment of rheumatoid arthritis. The two chemical constituents of sulphasalazine (sulphapyridine and 5-aminosalicylic acid) were assessed separately in the treatment of rheumatoid arthritis. Over 24 weeks sulphapyridine showed a pronounced second line effect comparable with sulphasalazine and with a similar toxicity profile, whereas 5-aminosalicylic acid showed only a weak first line effect. Thus sulphapyridine appears to be the active moiety responsible for the second line effect of sulphasalazine in rheumatoid arthritis.

The efficacy of the antibacterial component of sulphasalazine yet again permits speculation about the role of a bacterial pathogen in the aetiopathogenesis of rheumatoid disease.
\end{abstract}

\section{Introduction}

Sulphasalazine has recently been shown to be an effective second line agent in the treatment of rheumatoid arthritis. ${ }^{12}$ Only a small amount of ingested sulphasalazine, however, is absorbed and most reaches the large bowel unaltered, where it is split by bacterial action at its azo bond to sulphapyridine and 5 -aminosalicylic acid. Sulphapyridine is then almost completely absorbed and excreted via the kidneys unchanged or after hepatic metabolism. The 5-aminosalicylic acid, on the other

\footnotetext{
University Department of Medicine and Centre for Rheumatic Diseases, Royal Infirmary, Glasgow G4 OSF

T PULLAR, MB, MRCP, registrar

H A CAPELL, MB, MRCP, consultant

Gartnavel General Hospital, Glasgow

J A HUNTER, MB, MRCP, consultant
}

Correspondence to: Dr T Pullar, University Department of Medicine, General Infirmary, Leeds LS1 3EX. hand, remains largely in the bowel or undergoes enterohepatic circulation and is excreted in the faeces. Only very small amounts of 5-aminosalicylic acid reach the systemic circulation. ${ }^{3}$

In this study sulphapyridine and 5-aminosalicylic acid were administered separately to patients with rheumatoid arthritis in an attempt to identify the active moeity of sulphasalazine and to dissociate, if possible, toxicity and efficacy of the compound preparation.

\section{Patients and methods}

Sixty patients with classic or definite rheumatoid arthritis whose disease remained active despite adequate non-steroidal, antiinflammatory drugs were studied. Patients were randomly allocated to receive either sulphapyridine $2 \mathrm{~g} /$ day $(4 \times 500 \mathrm{mg}$ tablets $)$ or 5 aminosalicylic acid $1.2 \mathrm{~g} /$ day $(3 \times 400 \mathrm{mg}$ tablets) (30 patients per group).

The 5-aminosalicylic acid was given in the form of Asacol, which is not released until it reaches the large bowel and thus closely resembles the distribution of the 5-aminosalicylic acid component of sulphasalazine.

These doses were chosen as they represented, to the nearest tablet, the molar equivalents of these compounds contained in $3 \mathrm{~g}$ sulphasalazine, a dose we have previously found to be effective. ${ }^{2}$ Patients initially took one tablet a day, increasing each week by one tablet a day until the allocated dose was attained. All patients continued their original non-steroidal, anti-inflammatory drugs in a constant dose. Patients were excluded from the study if they had known sulphonamide or salicylate sensitivity or had received corticosteroid treatment or second line drugs in the three months preceding entry. No patient received corticosteroids or other second line drugs during the study.

Disease activity was assessed at weeks 0 and 24 using both laboratory (erythrocyte sedimentation rate, haemoglobin concentration, platelet count, IgM rheumatoid factor) and clinical (Ritchie articular index, pain score, hand grip strength, duration of morning stiffness) variables. The laboratories taking part were not aware of the patients' treatment, and all clinical assessments were carried out by a single metrologist, who, again, was blind to the patients' treatment. The physicians, however, were aware of the patients' treatment, and the patients were aware of whether they were receiving brown or white tablets but not of the names of the treatments.

In addition to disease activity assessment, toxicity monitoring consisted of assessing platelet count, haemoglobin concentration, and 
TABLE I-Reasons for and time of stopping treatment. Data show numbers of patients with week stopped in parentheses

\begin{tabular}{lcc}
\hline & Sulphapyridine $(\mathrm{n}=30)$ & 5-Aminosalicyclic acid $(\mathrm{n}=30)$ \\
\hline Nausea/vomiting & $6(1,1,4,6,7,9)$ & \\
$\begin{array}{l}\text { Rash } \\
\text { Dizziness }\end{array}$ & $4(2,4,6,6)$ & $1(4)$ \\
$\begin{array}{l}\text { Anxiety } \\
\text { Raised transaminase }\end{array}$ & $1(6)$ & \\
$\begin{array}{l}\text { concentrations } \\
\text { Indominal pain }\end{array}$ & $1(8)$ & \\
Inefficacy & $1(16)$ & $7(14,16,18,18,18,18,24)$ \\
Defaulted from clinic & $1(24)$ & $2(4,18)$ \\
\hline \multicolumn{1}{c}{ Total } & 14 & 10 \\
\hline
\end{tabular}

these indices at week 0 (Mann Whitney $U$ test, $p>0.05$ ). Little difference was apparent in the initial inflammatory indices at week 0 between those patients who continued treatment and those who stopped it before 24 weeks (table III). In the group treated with 5 -aminosalicylic acid, however, those patients who stopped treatment had a significantly greater initial value for serum IgM rheumatoid factor concentration (Mann Whitney $U$ test, $\mathrm{p}<0.005$ ).

Table IV shows the significance of the changes in the various indices between weeks 0 and 24 for the two groups and also the differences between the two groups at week 24 (Wilcoxon matched pairs signed rank test and Mann Whitney $U$ test, respectively) Most indices improved in the patients treated with sulphapyridine, whereas only articular index showed a significant improvement in

TABLE II-Median (range) values for indices of inflammation measured at 0 and 24 weeks

\begin{tabular}{|c|c|c|c|c|}
\hline & \multicolumn{2}{|c|}{ Sulphapyridine } & \multicolumn{2}{|c|}{ 5-Aminosalicylic acid } \\
\hline & Week $0(n=30)$ & Week $24(n=17)$ & Week $0(n=30)$ & Week $24(n=21)$ \\
\hline $\begin{array}{l}\text { Age (years) } \\
\text { Duration (years) } \\
\text { Erythrocyte sedimentation rate (mm in first hour) } \\
\text { Haemoglobin (g/dl) } \\
\text { Platelets }\left(\times 10^{\circ} / 1\right) \\
\text { Rheumatoid factor }(\mathrm{U} / \mathrm{ml}) \\
\text { Ritchie articular index } \\
\text { Pain score } \\
\text { Duration of morning stiffness (min) } \\
\text { Hand grip strength (mm Hg) }\end{array}$ & $\begin{array}{l}59(29-74) \\
7(1-40) \\
55(20-119) \\
11 \cdot 8(9 \cdot 5-14 \cdot 7) \\
377(230-556) \\
2470 \text { (Negative-10 324) } \\
15(0-37) \\
3 \cdot 2(1-4) \\
120(0-\text { All day) } \\
78 \text { (43-162) }\end{array}$ & $\begin{array}{l}56(29-74) \\
7(3-34) \\
18(5-51) \\
12 \cdot 7(9 \cdot 4-15 \cdot 5) \\
337(231-448) \\
1230 \text { (Negative-4650) } \\
5 \text { (0-23) } \\
2 \text { (0-4) } \\
30 \text { (0-All day) } \\
104(36-240)\end{array}$ & $\begin{array}{l}59(46-74) \\
12(1-29) \\
51(7-150) \\
12 \cdot 1(8 \cdot 9-17 \cdot 5) \\
416(196-679) \\
4864 \text { (Negative-31 400) } \\
18(4-39) \\
2 \cdot 9(1-4) \\
60(0-\text { All day) } \\
73 \text { (48-153) }\end{array}$ & $\begin{array}{l}59(49-74) \\
12(1-26) \\
58(5-132) \\
11 \cdot 3(6 \cdot 5-17 \cdot 0) \\
394(194-638) \\
4625 \text { (Negative-14 800) } \\
11 \text { (0-31) } \\
2(1-3) \\
60(5-\text { All day) } \\
71(45-138)\end{array}$ \\
\hline
\end{tabular}

TABLE III-Median (range) values for variables of rheumatoid arthritis measured at 0 weeks according to whether or not treatment was continued until 24 weeks

\begin{tabular}{|c|c|c|c|c|}
\hline & \multicolumn{2}{|c|}{ Sulphapyridine } & \multicolumn{2}{|c|}{ 5-Aminosalicylic acid } \\
\hline & Continued to 24 weeks & Stopped before 24 weeks & Continued to 24 weeks & Stopped before 24 weeks \\
\hline $\begin{array}{l}\text { Age (years) } \\
\text { Duration (years) } \\
\text { Erythrocyte sedimentation rate (mm in first hour) } \\
\text { Haemoglobin }(\mathrm{g} / \mathrm{dl}) \\
\text { Platelets }\left(\times 10^{\circ} / 1\right) \\
\text { Rheumatoid factor }(\mathrm{U} / \mathrm{ml}) \\
\text { Ritchie articular index } \\
\text { Pain score } \\
\text { Duration of morning stiffness (min) } \\
\text { Hand grip strength (mm Hg) }\end{array}$ & $\begin{array}{l}56(29-74) \\
7(3-40) \\
51(35-92) \\
12 \cdot 6(9 \cdot 5-14 \cdot 5) \\
385(330-556) \\
4250(0-7362) \\
13(0-31) \\
3 \cdot 2(1-4) \\
90(0-A 11 \text { day) } \\
80(45-162)\end{array}$ & $\begin{array}{c}59(32-72) \\
6(1-27) \\
66(20-119) \\
11 \cdot 8(9 \cdot 7-14 \cdot 7) \\
343(230-483) \\
2470(0-10324) \\
15(0-37) \\
3 \cdot 2(2-4) \\
120(0-\text { All day }) \\
72(43-104)\end{array}$ & $\begin{array}{l}59(49-74) \\
12(1-26) \\
50(7-114) \\
12 \cdot 1(8 \cdot 7-17 \cdot 5) \\
429(196-679) \\
2435(0-7739) \\
16(4-35) \\
2 \cdot 9(1-4) \\
60(0-A 11 \text { day) } \\
73(50-107)\end{array}$ & $\begin{array}{c}52(46-69) \\
13(3-29) \\
78(20-150) \\
12 \cdot 9(9 \cdot 8-16 \cdot 5) \\
472(323-653) \\
16166(5045-31400) \\
18(8-39) \\
2 \cdot 9(1-4) \\
120(0-A 11 \text { day }) \\
70(48-153)\end{array}$ \\
\hline
\end{tabular}

*IgM rheumatoid factor significantly greater in those who stopped treatment (Mann Whitney, $\mathrm{p}<0.005$ ).

TABLE IV-p Values for differences between values in weeks 0 and 24 (Wilcoxon matched pairs signed rank test) and between values obtained in week 24 in patients taking 5-aminosalicylic acid and those obtained in patients taking sulphapyridine (Mann Whitney $U$ test)

\begin{tabular}{|c|c|c|c|}
\hline & $\begin{array}{c}\text { Sulphapyridine } \\
\text { (week 0v week 24) } \\
(\mathrm{n}=17)\end{array}$ & $\begin{array}{c}\text { 5-Aminosalicylic acid } \\
\text { (week } 0 v \text { week 24) } \\
(\mathrm{n}=21)\end{array}$ & $\begin{array}{c}\text { Week 24 } \\
\text { (sulphapyridine } v \text { 5-aminosalicylic acid) }\end{array}$ \\
\hline $\begin{array}{l}\text { Erythrocyte sedimentation rate } \\
\text { Haemoglobin concentration } \\
\text { Platelets } \\
\text { Rheumatoid factor } \\
\text { Ritchie articular index } \\
\text { Pain score } \\
\text { Duration of morning stiffness } \\
\text { Hand grip strength }\end{array}$ & $\begin{array}{l}0.0018^{* * *} \\
0 \cdot 18 \\
0.0032^{* * *} \\
0.01 * * \\
0.0024^{* * *} \\
0.028^{*} \\
0.02^{*} \\
0.0024^{* * *}\end{array}$ & $\begin{array}{l}0.24 \\
0.0086^{* *} \text { (deterioration) } \\
0.48 \\
0.026^{*} \text { (deterioration) } \\
0.0044^{* * *} \\
0.5 \\
0.26 \dagger \\
0.18 \dagger\end{array}$ & $\begin{array}{l}0.0016^{* * *} \\
0 \cdot 16 \\
0 \cdot 19 \\
0 \cdot 64 \\
0.021^{* *} \\
0 \cdot 14 \\
0.46 \\
0.001 * * * *\end{array}$ \\
\hline
\end{tabular}

V Values: ${ }^{*}<0.05 ;^{* *}<0.01 ;{ }^{* * *}<0.005 ; * * * * 00.001$

$\uparrow$ Trend towards deterioration.

white cell count at weeks $0,2,4,6,8,10,12,18$, and 24 and liver function tests at weeks $0,6,12$, and 24 . IgM rheumatoid factor was measured using an enzyme linked immunosorbent assay technique and is expressed here in $\mathrm{U} / \mathrm{ml}$.

\section{Results}

At 24 weeks 21 patients $(70 \%)$ were still taking 5 -aminosalicylic acid and $17(57 \%)$ sulphapyridine. Table I shows reasons for and time of stopping treatment. Table II shows age, duration of disease, and median (range) values for inflammatory indices at weeks 0 and 24 . No significant differences were seen between the groups for any of those receiving 5-aminosalicylic acid; this group also showed a deterioration in haemoglobin concentration and $\operatorname{IgM}$ rheumatoid factor. For several indices (erythrocyte sedimentation rate, articular index, and grip strength) the patients treated with sulphapyridine were significantly better than those treated with 5-aminosalicylic acid after 24 weeks. The figure shows the pattern of change in some selected inflammatory indices.

\section{Discussion}

The first published report in English of the use of sulphasalazine appeared in 19424: Nanna Svarz described an un- 

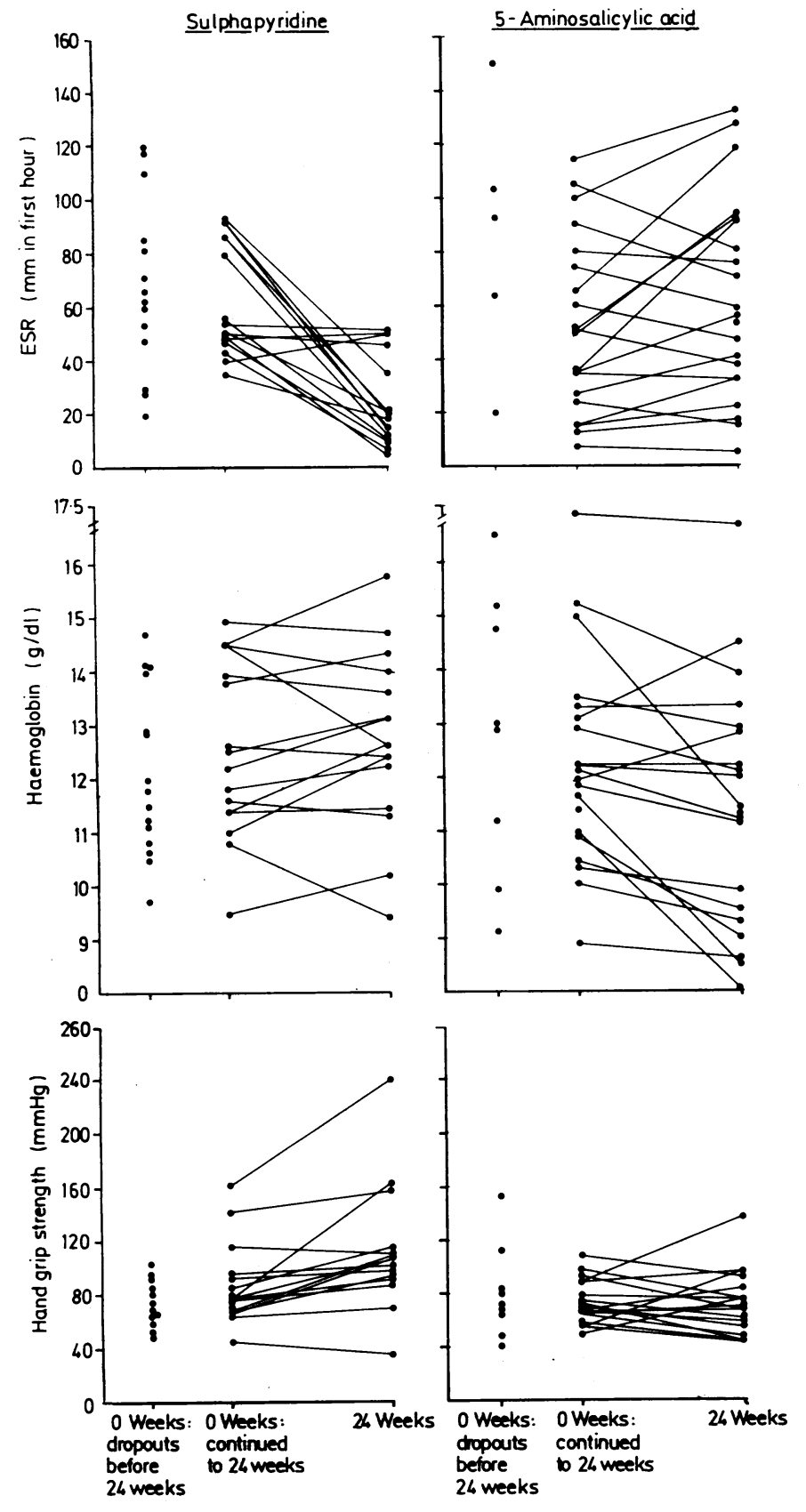

Pattern of change in erythrocyte sedimentation rate (ESR), haemoglobin concentration, and hand grip strength over 24 weeks of study.

controlled study of 20 patients (11 with "rheumatic polyarthritis" and nine with ulcerative colitis) who improved with this drug. The rationale for using sulphasalazine was that it combined a sulphonamide that had been effective in septic arthritis with a salicylate. Most of the evidence available at that time, however, suggested that sulphonamides alone were not effective in rheumatoid arthritis, although it has been suggested that soluseptasine, an intramuscular sulphonamide preparation, was effective. ${ }^{6}$ Over the next few years further uncontrolled studies suggested sulphasalazine to be an effective antirheumatic drug. ${ }^{7} 8$ In 1948 a controlled study comparing 20 patients receiving sulphasalazine, 20 receiving gold, and 20 receiving "no specific ireatment" failed to show any difference between the treatment groups, ${ }^{9}$ and sulphasalazine, but not gold, subsequently fell out of favour. This study, however, was analysed with the now outdated concept of a "course of gold," and the assessment of both gold and sulphasalazine treated patients was in many cases carried out many months after treatment had been stopped. In addition, patients in all groups underwent long periods of bed rest with a median period of nine weeks in hospital. These confounding factors make it difficult to draw any conclusions from this study. Interest in sulphasalazine in rheumatoid arthritis was rekindled 30 years later when an open trial of 32 patients treated with $3 \mathrm{~g} /$ day over 22 weeks suggested a second line effect. ${ }^{10}$ This group of patients was expanded and follow up prolonged, and again significant improvement was seen. ${ }^{1}$ Bird et al have exposed sulphasalazine to their mini-matrix ${ }^{11}$ and again suggested it to have second line effects. ${ }^{1:}$ Two controlled studies have shown similar improvement in patients treated with sulphasalazine and penicillamine ${ }^{13}$ and in patients treated with sulphasalazine and gold but not in placebo treated groups. ${ }^{2}$ More recently a direct relation between dose and efficacy of sulphasalazine has been shown. ${ }^{14}$

The study described in this paper shows an unequivocal second line effect-that is, improvement in both laboratory and clinical indices of inflammation-in the rheumatoid patients receiving sulphapyridine and implies therefore that sulphapyridine is the active moiety of sulphasalazine, although previous work has been unable to show any relation between serum concentrations of sulphapyridine or its metabolites and the therapeutic efficacy of sulphasalazine in rheumatoid arthritis. ${ }^{14}$ The patients treated with 5 -aminosalicylic acid showed a significant improvement in articular index alone and a fall in haemoglobin concentration. We might postulate that 5-aminosalicylic acid shows a mild non-steroidal, anti-inflammatory drug type action, and the deterioration in haemoglobin concentration might even have represented gastrointestinal blood loss commonly seen with such drugs. IgM rheumatoid factor, however, also deteriorated, and this group might have been getting worse. The slight symptomatic improvement with 5-aminosalicylic acid may, nevertheless, have allowed more patients to continue this drug for 24 weeks despite the absence of a second line effect and thus enable us to show a difference between the two agents that is rarely seen between active drug and placebo. ${ }^{15}$

Sulphasalazine has been used for many years in the treatment of inflammatory bowel disease, and the recent suggestion that the active moiety in this condition is 5 -aminosalicylic acid ${ }^{16}{ }^{17}$ is in direct contrast with our findings in patients with rheumatoid arthritis.

This evidence that sulphapyridine is active in the treatment of rheumatoid arthritis raises two major questions. The lesser of these is whether we should now use sulphapyridine in preference to sulphasalazine in the treatment of rheumatoid arthritis.

These results in the patients treated with sulphapyridine are similar to those in our first 30 patients treated with sulphasalazine: in terms of both pattern of efficacy and toxicity profile. Eighteen patients continued to take sulphasalazine past 24 weeks compared with 16 who continued sulphapyridine (one patient stopped at week 24 and data were therefore analysed on 17), with six patients stopping each treatment because of upper gastrointestinal symptoms. Subsequent studies with sulphasalazine from this unit have shown a lower dropout rate. ${ }^{14}$ This may merely represent our increasing experience with sulphasalazine (including the use of prochlorperazine symptomatically for nausea), or it may be that sulphasalazine really is better tolerated. It should be pointed out, however, that we used an equimolar dose to the nearest whole tablet. Thus the exact equimolar dose to $3 \mathrm{~g}$ sulphasalazine would be $1.8 \mathrm{~g}$ sulphapyridine rather than the $2 \mathrm{~g}$ used here. In addition, a proportion of ingested sulphasalazine is excreted unchanged, and the bioavailable sulphapyridine in $3 \mathrm{~g}$ sulphasalazine is therefore further reduced. Thus before we change our practice further comparative studies of the two drugs are required and perhaps also the investigation of less toxic sulphonamide preparations would be productive.

The more important question posed by this study relates to the implications for the pathogenesis of rheumatoid arthritis. It has been suggested that rheumatoid arthritis is an enteropathic arthropathy, ${ }^{18}$ and interference with colonic bacteriology has 
previously been put forward as one of the possible modes of action of sulphasalazine. ${ }^{19}$ Either sulphapyridine by exerting an antibacterial effect or 5-aminosalicylic acid by a local antiinflammatory effect on the bowel wall could conceivably hold theoretical claims to such an effect. The fact that sulphapyridine is the active component might therefore suggest a role for bacterial infection in the causation or perpetuation of the rheumatoid disease process. Sulphapyridine is, however, well absorbed, and such organisms could be localised systemically (perhaps even in the synovium) as well as within the bowel lumen. Although such hypotheses are of interest, it must be remembered that other antirheumatic drugs such as gold, penicillamine, and chloroquine were all introduced initially for diseases other than rheumatoid arthritis and that sulphapyridine may therefore be effective for some reason other than its antimicrobial properties. Two of the above named agents were, however, initially used as antimicrobials-gold against tuberculosis and chloroquine against malaria. In addition, the third drug, penicillamine, is closely related structurally to penicillin. Thus we should perhaps not dismiss too soon the suggestion that bacteria have a part to play in the aetiopathogenesis of rheumatoid arthritis. Much work remains to be done on this subject.

In conclusion, sulphapyridine is an active second line agent in rheumatoid arthritis but the ratio of efficacy to toxicity is no better than with sulphasalazine. In addition, although its mode of action may be unrelated to its antibacterial action, the finding that an antibiotic is effective in reducing inflammation in rheumatoid arthritis should promote a further search for a bacterial cause.

We thank Dr R D Sturrock for allowing us to study his patients; Mrs E A Thompson for metrological help; Miss C Wilson for typing the manuscript; Tillotts Laboratories for supplying 5-aminosalicylic acid in the form of Asacol; and May and Baker for supplying sulphapyridine. Measurements of rheumatoid factor were kindly carried out by $\mathrm{Dr} \mathrm{K}$ Whaley and staff at the Western Infirmary, Glasgow.

\section{References}

1 McConkey B, Amos RS, Durham S, et al. Sulphasalazine in theumatoid arthritis. BrMed F 1980;280:442-4.

Pullar T, Hunter JA, Capell HA. Sulphasalazine in rheumatoid arthritis: double blind comparison of sulphasalazine with placebo and sodium aurathio-

late. Br Med f 1983;287:1102-4.

4 Svarz N. Salazopyrine, a new sulfamilamide preparation. Acta Med Scand $1942 ; 6: 577-98$

5 Anonymous. Salazopyrine and some side issues [Editorial]. Lancet 1943;i:181-2. 6 Shea BF. Soluseptasine in rheumatoid arthritis. Br Med 7 1943;i:30.

7 Svartz $\mathrm{N}$. The treatment of rheumatic polyarthritis with acid azo compounds. Rheumatism 1948;4:180-5.

8 Kuzell WK, Gardner GM. Salicylazosulfapyridine (salazopyrin or azopyrin) in rheumatoid arthritis and experimental polyarthritis. California Medicine 1950 73:476-80

9 Sinclair RJG, Duthie JJR. Salazopyrine in the treatment of rheumatoid arthritis. Ann Rheum Dis 1948:8.226-31.

McConkey B, Amos RS, Butler RA, et al. Salazopyrine in rheumatoid arthritis. Agents Actions 1978;8:38-41

11 Dixon JS Bird for its detectio

12 Bird HA, Dixon JS, Pickup ME, et al. A biochemical assessment of sulphasalazin in rheumatoid arthritis. $\mathcal{F}$ Rheumatol 1982;9:36-45.

13 Neumann VC, Grindulis KA, Hubball S, McConkey B, Wright V. Compariso between penicillamine and sulphasalazine in rheumatoid arthritis: Leed Birmingham trial. Br Med f 1983;287:1089-102.

14 Pullar T, Hunter JA, Capell HA. Sulphasalazine in the treatment of rheumatoid press).

15 Pullar

T, Capell HA. A rheumatological dilemma: is it possible to modify the course of rheu

16 Dew MJ, Hughes $P$, Harries AD, et al. Maintenance of remission in ulcerative colitis with oral preparations of 5-aminosalicylic acid. $\mathrm{Br}$ Med $\mathcal{F} 1982 ; 285$ : $1012-3$

17 Dew MJ, Harries AD, Evans N, Evans BK, Rhodes J. Maintenance of remission in ulcerative colitis with 5 -aminosalicylic acid in high doses by mouth. $B$ Med F 1983;287:23-4

18 Anonymous. Rheumatoid arthritis and the gut [Editorial]. Br Med f 1979;i:1104 (new" anti-rheumatic drug. $\mathrm{Br}$

(Accepted 14 March 1985)

100 YEARS AGO

The withdrawal of the troops from the Soudan is being carried out with great rapidity. During the past three weeks, all the summer camps have been evacuated, and nearly all corps and battalions forming the Nile Expeditionary Force have passed through Abu Fatmeh on their return march. All regiments, on the return journey, whether by river or route march, proceed in columns of half-battalions, each accompanied by a medical officer provided with a sufficiency of medicines, medical comforts, and equipment. The Royal Highlanders, Essex Regiment, and Light Camel Regiment proceeded downwards from Abu Fatmeh in whalers; the Guards Camel Regiment and Heavy Camel Regiment performed the journey by march route; whilst the Gordon Highlanders, the Duke of Cornwall's Light Infantry, the Royal Irish and the Royal Sussex Regiments proceeded half by whalers and half by route march. All columns moving to the north are directed to proceed by night-marches on successive days. The hour of starting is left to the officers commanding columns, but must be such as to secure the troops from marching in the heat of the sun, and not earlier than 5 P.M. Each column going by route march has orders to detail five boats' crews for the five whalers detailed for the carriage of the kits, regimental luggage, and as much of the spare ammunition as can be carried. The troops only carry their rifles, with 10 rounds of ammunition for each man. As the desertjourney from Abu Fatmeh to Kaibar cannot be accomplished in one march, the officer commanding is instructed to decide on the distance to be marched before halting to bivouac, but should arrange that at least half the distance to Kaibar should be covered before night. The men get tea and biscuit as soon as possible after halting to bivouac; this is additional to the regular evening meal, which is taken before starting. Water-bottles are filled just before starting. The scale of transport for each column on the march is: for carrying water, nine camels; wood, cooking-pots, etc., four camels; blankets (one for each man), four or five camels, as required; officers, two camels; medical officers, two camels; cacolets and litters, three camels. In addition to the camels with cacolets and litters, six donkeys are sent with each column, to carry men falling out, who may be able to ride. The camels for carrying wood and water return from the bivouac, unless the officer commanding, or medical officer in charge, should consider that insufficient transport has been provided for the sick, in which case authority is given to take on as many camels as may be required. It is ordered that the hour for starting from the bivouac is to be sufficiently early to ensure arrival at Kaibar withou unnecessary exposure of the men to the sun. An extra half ration of tea and biscuit is issued for the desert march, and arrangements are made for giving tea and biscuit in the morning before starting. Arrangements are also made for shelter and water at Faregh, where the columns first strike the river in the morning. All precautions are directed to be taken to prevent the men from unnecessarily uncovering their heads in the sun, and they are cautioned against exhausting their water-bottles early in the march. All necessary measures are taken to prevent sore feet. From Kaibar the column proceed on successive days to the following halting-places: Dulgo, Absarat, Sayed Effendi, Koyeh Matto, Ucha Matto. One day's halt is made here, and the daily march continued to Koyeh, Abri, Mograkeh and Sarkamatto. From Sarkamatto the troops will, as far as possible, be taken in boats to Kasheh, whence they will march direct to Rail Head, and thence proceed by rail to Wady Halfa. In order that the five whalers, detailed for each column, may be able to meet the troops on their arrival early in the morning at each station, they are directed to be ready at 3 A.M., and to start each morning not late than 4 o'clock, so as to reach the next station before 8 o'clock. Rations will be issued at each station, and filtered water will be prepared as far as possible, and in readiness for the columns. A regulated scale of transport has been arranged to accompany each column. In addition to the hospitals established along the lines of communication, and the increase of the hospital at Kaibar to fifty beds, two new hospitals have been formed for twenty-five beds each, at Koyeh Matto and Abri, under Surgeons Allin and Chester respectively. Any men falling sick are carried to the nearest station, and removed by whalers to the nearest hospital down stream. Columns proceeding north, by river route, are told off into company sections of four or five whalers, and for each section two Egyptian soldiers are detailed who thoroughly know the river; and the strictest precautions are ordered regarding the safety of the whalers in passing through the rapids. These sections are to keep together, and are on no account to be broken up, but each section is allowed to proceed north as fast as possible. (British Medical Fournal 1885;ii:121.) 